\title{
Ultrastructural changes in hepatopancreatic cells of the prawn Palaemon serratus induced by exposure to acutely toxic cadmium concentrations
}

\author{
E. Papathanassiou* \& P. E. King \\ Department of Zoology, University College of Swansea, United Kingdom
}

\begin{abstract}
Accumulation of cadmium in the hepatopancreas of the common prawn Palaemon serratus (Pennant) and ultrastructural changes in hepatopancreatic cells were examined after exposure to 3 cadmium concentrations $(5,25,50 \mathrm{ppm})$ for $44 \mathrm{~h}$. Accumulation of cadmium ions in 50 ppm solution was $800 \%$ higher compared with control specimens. Absorptive and fibrillar cells ( $\mathrm{R}$ - and F-cells) in the hepatopancreas were affected by cadmium ions at the ultrastructural level. The ultrastructural changes observed suggest impairment of ion transport, absorption and protein synthesis.
\end{abstract}

\section{INTRODUCTION}

The crustacean hepatopancreas functions in food absorption, secretion of digestive enzymes and storage of lipid material (Vonk 1960, Steeves 1969). Ultrastructural studies confirmed results of early light microscope research and related morphological features with the cell's function (Donadey 1969, Loizzi 1971). From these studies it has been established that in the hepatopancreas of Decapoda 4 types of cells are present: E-cells (embryonic cells), R-cells (absorptive cells), F-cells (fibrillar cells) and B-cells (secretory cells) (Davis \& Burnett 1964, Bunt 1968, Stanier et al. 1968, Gibson \& Barker 1979). There were conflicting results, however, regarding the origin of these cells which depends on the animal's state of nutrition (Stanier et al. 1968). Papathanassiou \& King (1984) studied the effects of starvation on the fine structure of the hepatopancreas of Palaemon serratus (Pennant), an ecologically important species in British waters.

Accumulation of cadmium ions by the crustacean's hepatopancreas under natural and experimental conditions have been studied by several authors (O'Hara 1973b, Hutcheson 1974). Nimmo et al. (1977) studied the effects of cadmium in the shrimp Penaeus duorarum Bukenroad, Palaemonetes pugio Holthius

\footnotetext{
- Present address: National Center for Marine Research, Agios Kosmas, GR-166 04 Hellinikon, Athens, Greece
}

and Palaemon vulgaris L. They found significant accumulation of cadmium by the hepatopancreas of controls after $96 \mathrm{~h}$. The rate of uptake in the hepatopancreas was considerably higher than in the gills in the 3 species, and these values for both tissues increased in relation to the concentration.

The present study examines the ultrastructural changes in the cells of hepatopancreas of Palaemon serratus and the accumulation of cadmium ions in the tissue of specimens exposed to acutely toxic $\mathrm{Cd}$ concentrations.

\section{MATERIALS AND METHODS}

Specimens of Palaemon serratus (Pennant) were collected at Mumbles Point, Swansea, U. K., at low tide, and kept alive in circulating seawater for $1 \mathrm{wk}$ before use. After this acclimation period, groups of 20 active individuals were placed in crystallizing dishes containing $1 \mathrm{l}$ of $30 \mathrm{ppt}$ artificial seawater at $15^{\circ} \mathrm{C}$. Screening tests showed that the cadmium concentrations, added as $\mathrm{CdCl}_{2} \cdot 2 \frac{1}{2} \mathrm{H}_{2} \mathrm{O}$, causing morphological effects on the hepatopancreas of $P$. serratus varied between 5 and $50 \mathrm{ppm}$. Thus the specimens were placed in 3 cadmium concentrations viz. 5, 25 and $50 \mathrm{ppm}$. These concentrations were determined before starting the experiments using an Atomic Absorption Spectrophotometer. The maximum $1.5 \%$ variation 
observed was considered to be insignificant. A fourth group of 20 active individuals was placed in clean 30 ppt seawater as controls. The seawater was made up by dissolving 'Tropical Marine' salts (Shirley Aquatics Ltd., Solihull, England) in glass-distilled water. Observations were carried out every $6 \mathrm{~h}$ and dead individuals were removed. Solutions were renewed after the first $24 \mathrm{~h}$. After $44 \mathrm{~h}$, which is the lethal time for $50 \%$ of the individuals placed in $50 \mathrm{ppm}$ cadmium at $15^{\circ} \mathrm{C}$ (Papathanassiou 1984), a number of groups of 10 live individuals were removed from each concentration including controls.

The hepatopancreas was dissected from each individual of each group and dried at $105^{\circ} \mathrm{C}$ for $24 \mathrm{~h}$. These tissue samples were then weighed (dry weight $0.30 \pm$ $0.02 \mathrm{~g}$ ) to the nearest $0.1 \mathrm{mg}$ and digested in 5:1 nitric: perchloric acid at $120^{\circ} \mathrm{C}$. Four replicates were used for each concentration and the accumulation of cadmium was determined using a Corning-Eel 240 Mark II Atomic Absorption Spectrophotometer.

For electron microscopy the hepatopancreas from at least 8 specimens of each group was fixed for $1 \mathrm{~h}$ in $5 \%$ cacodylate buffered glutaraldehyde with sucrose added at 0 to $4{ }^{\circ} \mathrm{C}$. It was then washed in several changes of buffered sodium cacodylate with sucrose added, followed by post-fixation in $1 \%$ osmium tetroxide solution for $1 \mathrm{~h}$ at 0 to $4{ }^{\circ} \mathrm{C}$. After dehydration in graded cold acetone the material was embedded in TAAB embedding resin. Sections with gold or silver interference colours were obtained using a Huxley Mark I Ultramicrotome and were mounted on coated copper grids. They were then double stained in $30 \%$ uranyl acetate $(30 \mathrm{~min})$ followed by lead citrate $(10$ min) and viewed in a Corinth AEI Electron Microscope. The hepatopancreatic cells examined were from every part of the tubule and more than $90 \%$ showed the characteristics that are described in the results.

\section{RESULTS}

Accumulation of cadmium by the hepatopancreas of control prawns was significantly higher than in control individuals ( $p<0.001$ ). The value of accumulated cadmium increased with the concentration of the medium. Table 1 gives the mean values of accumulated cadmium concentrations in the hepatopancreas after $44 \mathrm{~h}$ exposure to cadmium ions.

The types of cells in the hepatopancreas of Palaemon serratus have been studied by Papathanassiou \& King (1984). Fig. 1.1, 1.2, $1.3 \& 1.4$ show the 4 types of cells existing in control specimens

The absorptive cells differentiated after exposure to cadmium ions. After exposure to 5 ppm the basement membrane had fewer infoldings associated with
Table 1. Palaemon serratus. Mean values of accumulated cadmium concentrations (dry weight) in the hepatopancreas after $44 \mathrm{~h}$ of $\mathrm{Cd}$ exposure. Values in parentheses represent \% of increase over controls

\begin{tabular}{|cc|}
\hline $\begin{array}{c}\text { Concentration } \\
(\mathrm{ppm})\end{array}$ & $\begin{array}{c}\text { Cadmium accumulated in } \\
\text { hepatopancreas } \\
(\mathrm{ppm} \pm \mathrm{SD})\end{array}$ \\
\hline $\begin{array}{c}\text { Control } \\
5\end{array}$ & $12.4 \pm 3.9$ \\
25 & $31.3 \pm 5.2(152.4)$ \\
50 & $49.6 \pm 10.3(300.0)$ \\
& $112.4 \pm 13.3 \quad(806.4)$ \\
\hline
\end{tabular}

mitochondria and fewer smooth endoplasmic reticulum vesicles (Fig. $2 \& 3.1$ ). Some of these mitochondria possessed fewer cristae than in clean specimens, some of which degenerated (Fig. 3.3). The cisternae of the rough endoplasmic reticulum were shorter and thinner than in clean specimens and surrounded the nucleus. At the apical region, the cell possessed less endoplasmic reticulum, which was mostly in vesicular form (Fig. 3.5). At the apical region of those cells were fewer mitochondria than in clean specimens. Proximal to the microvilli of the apical cell membrane were lipid droplets and some autophagic vacuoles (Fig. 3.2).

After exposure to $25 \mathrm{ppm}$ the mitochondria had swollen cristae and were fewer in number when compared with either the R-cells of clean or $5 \mathrm{ppm}$ specimens (Fig. $2 \& 3.4$ ). In some of these mitochondria, the bounding membranes were separated from each other, resulting in a swollen appearance. In the apical region of some cells, the endoplasmic reticulum had a vesicular form, while in others it had the form of short and thin cisternae (Fig. $3.6 \& 4.6$ ). In the central and basal region the rough endoplasmic reticulum had the form of concentric whorls (Fig. 3.4). In the basal region of the cell, the basement membrane had fewer infoldings than that in either clean or 5 ppm specimens (Fig. 4.5). The cytoplasm also possessed large vacuoles (Fig. 3.4).

After exposure to $50 \mathrm{ppm}$ cadmium the 2 membranes of the nuclear envelope were either partially separated or disrupted in places (Fig. $2 \& 4.1$ ). The apical region of the cells had fewer microvilli, which had an undulating appearance (Fig. 4.2). Mitochondria at the apical region of the cell were fewer but larger and contained packed cristae (Fig. 4.3). The mitochondria in the basal region of the cell differed from those in the apical region by having few and swollen cristae (Fig. 4.4). The cisternae of the rough endoplasmic reticulum had a swollen appearance. The basement membrane was distorted with short infoldings and there were fewer mitochondria and vesicles of the smooth endoplasmic reticulum (Fig. 4.4).

In F-cells after exposure to $5 \mathrm{ppm}$ cadmium the 

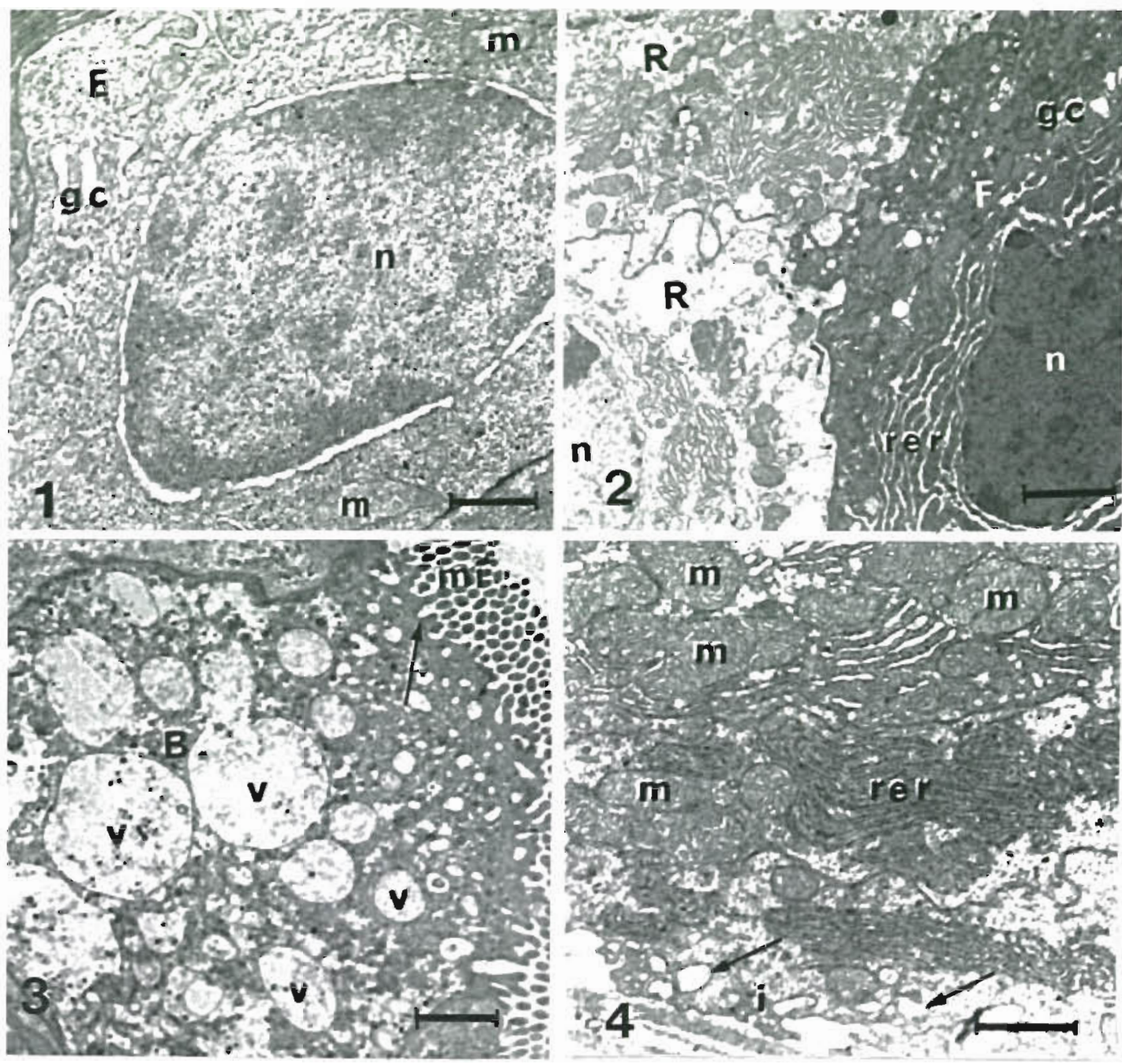

Fig 1 Palaemon serratus. Electron micrographs. (1) Embryonic cell (E); note small number of mitochondna (m); scale bar $=$ $1 \mu \mathrm{m}$ (2) Fibrillar cell (F): note abundant rough endoplasmic reticulum (rer); scale bar $=2 \mu \mathrm{m}$. (3) Secretory cell (B); note numerous vesicles ( $\mathrm{v}$ ) within the cell, and undulating appearance of apical membrane (arrow). scale bar $=1.4 \mu \mathrm{m}$. (4) Basal region of an absorptive cell; note ınfoldıngs of basement mebrane (i) associated with vesicles (arrows); scale bar $=1$ um. gc:

Golgı complex; n. nucleus; m. mitochondna; mı: mıcrovilli; rer: rough endoplasmic reticulum

cisternae of the rough endoplasmic reticulum were shorter and more dilated in places than those in control individuals (Fig. 2 \& 5.1). After exposure to $25 \mathrm{ppm}$ cadmium these cells possessed abundant rough endoplasmic reticulum with shorter cisternae than those in F-cells of either clean or 5 ppm individuals (Fig. 2 \& 5.2). In the F-cells of specimens exposed to $50 \mathrm{ppm}$ the cisternae of the rough endoplasmic reticulum were abundant, and in some cells were considerably shorter than in clean, 5 ppm or 25 ppm specimens (Fig. 2 \& 5.3). However, in some other F-cells, extended cisternae of the rough endoplasmic reticulum were present (Fig. 5.4). The mitochondria at the apical region of the cell were larger and fewer when compared with clean, 5 ppm or 25 ppm specimens (Fig. 5.3).

\section{DISCUSSION}

The concentrations of cadmium used in the present study were much higher than those occurring naturally in Bntısh wates (Abdullah et al. 1972, Preston 1973). However, high concentrations of heavy metals in the environment could be a result of a sudden release of industrial effluents. From the present study, which reports morphological changes in the hepatopancreatic cells of Paldemon serratus after exposure to high cadmium concentrations, it is apparent that mainly Fcells and R-cells are affected.

Accumulation of cadmum in the hepatopancreas, after exposure to high concentrations for $44 \mathrm{~h}$, did not exceed $115 \mathrm{ppm} \mathrm{Cd}$ dry weight: possibly, this is the 
A
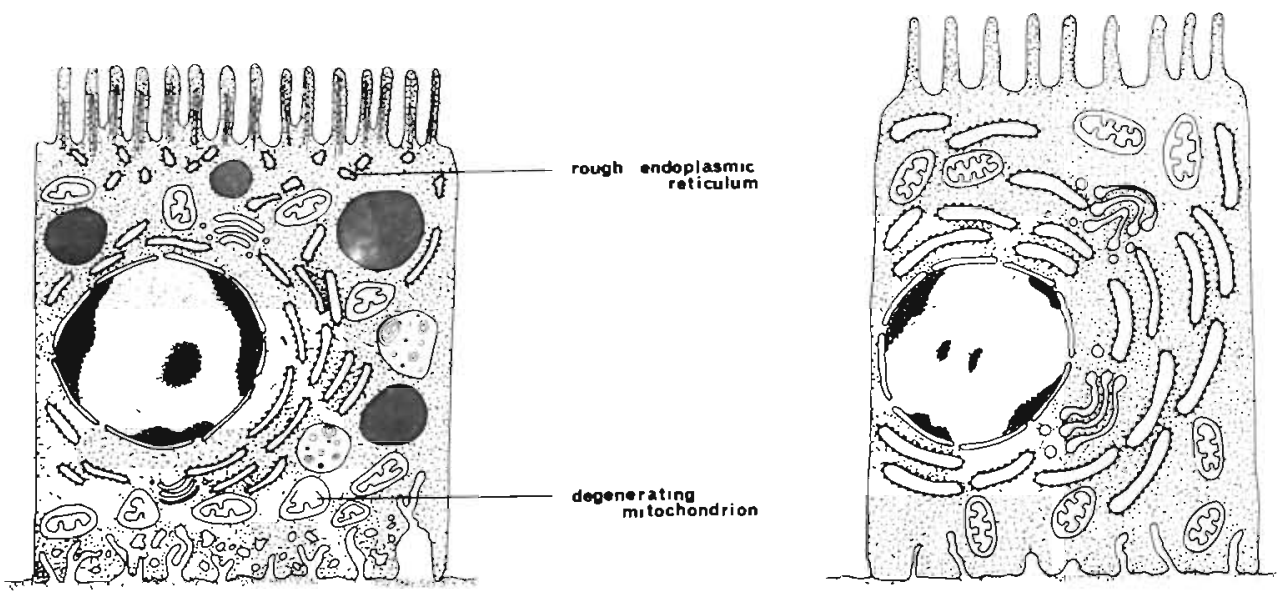

1

\section{2}

B

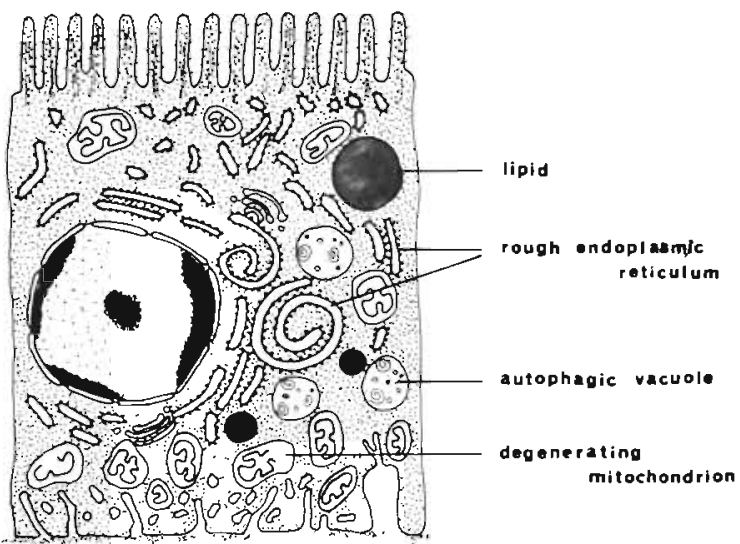

1

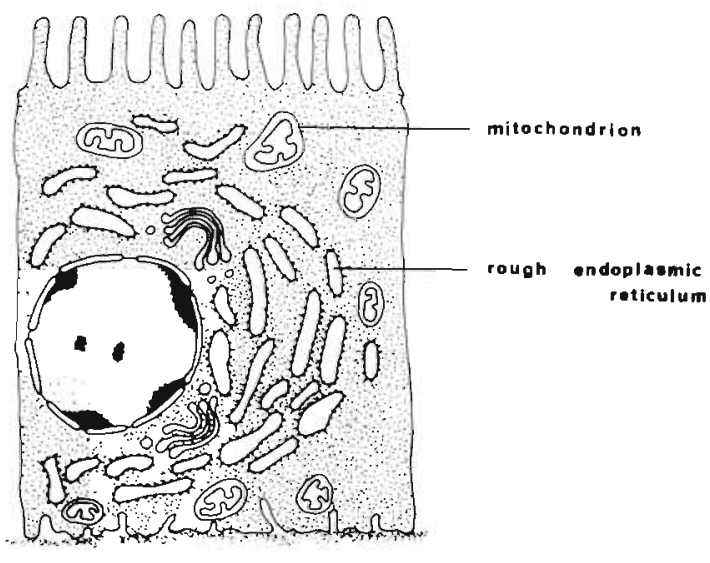

2
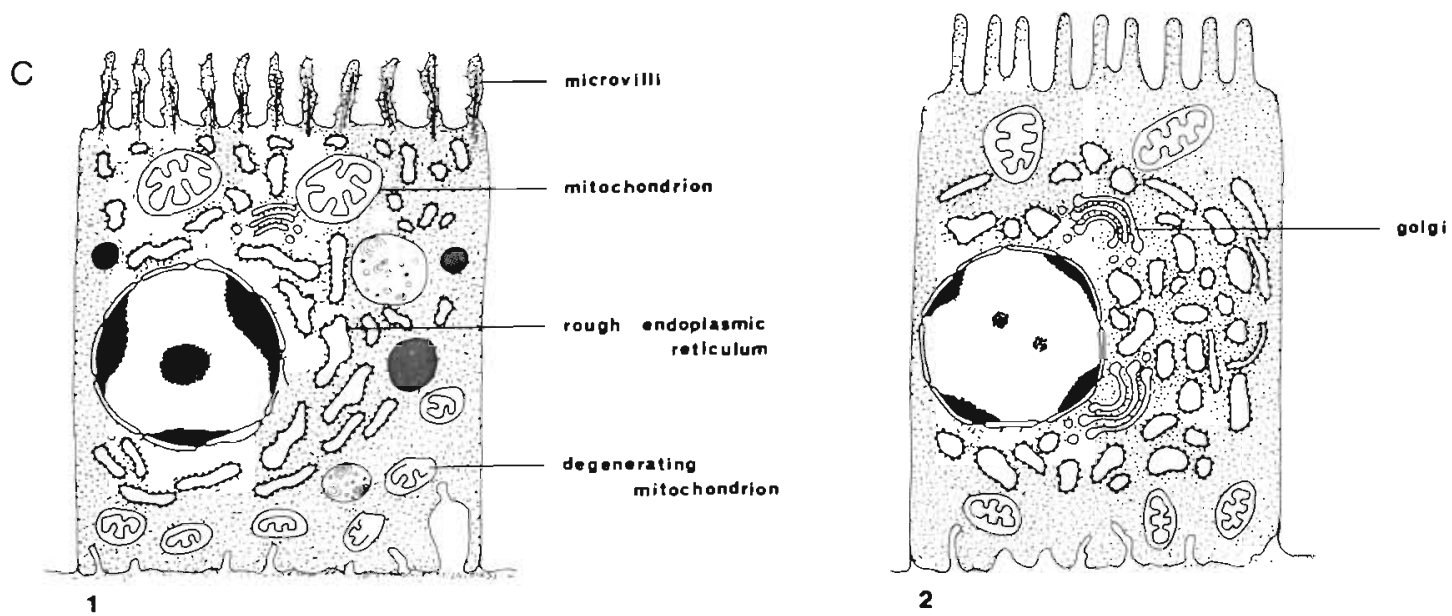

Fig. 2. Palaemon serratus. Fine structure of hepatopancreatıc cells after exposure to $5 \mathrm{ppm}$ (A), $25 \mathrm{ppm}$ (B) and $50 \mathrm{ppm}$ (C) of cadmum. (1) Absorptuve cell: (2) tibrillar cell.

maximum level for $\mathrm{Cd}$ accumulation since specimens died shortly after this level was reached (Papathanassiou 1984). After this level of Cd accumulation, a decline was reported in $U_{C a}$ pugilator (Bosh.) which was attributed to tissue breakdown (O'Hara 1973a). O Hara (1973b) suggested that high metabolic activity of $U$. pugilator may contribute to the high rate of translocation of cadmium from the gills to the 


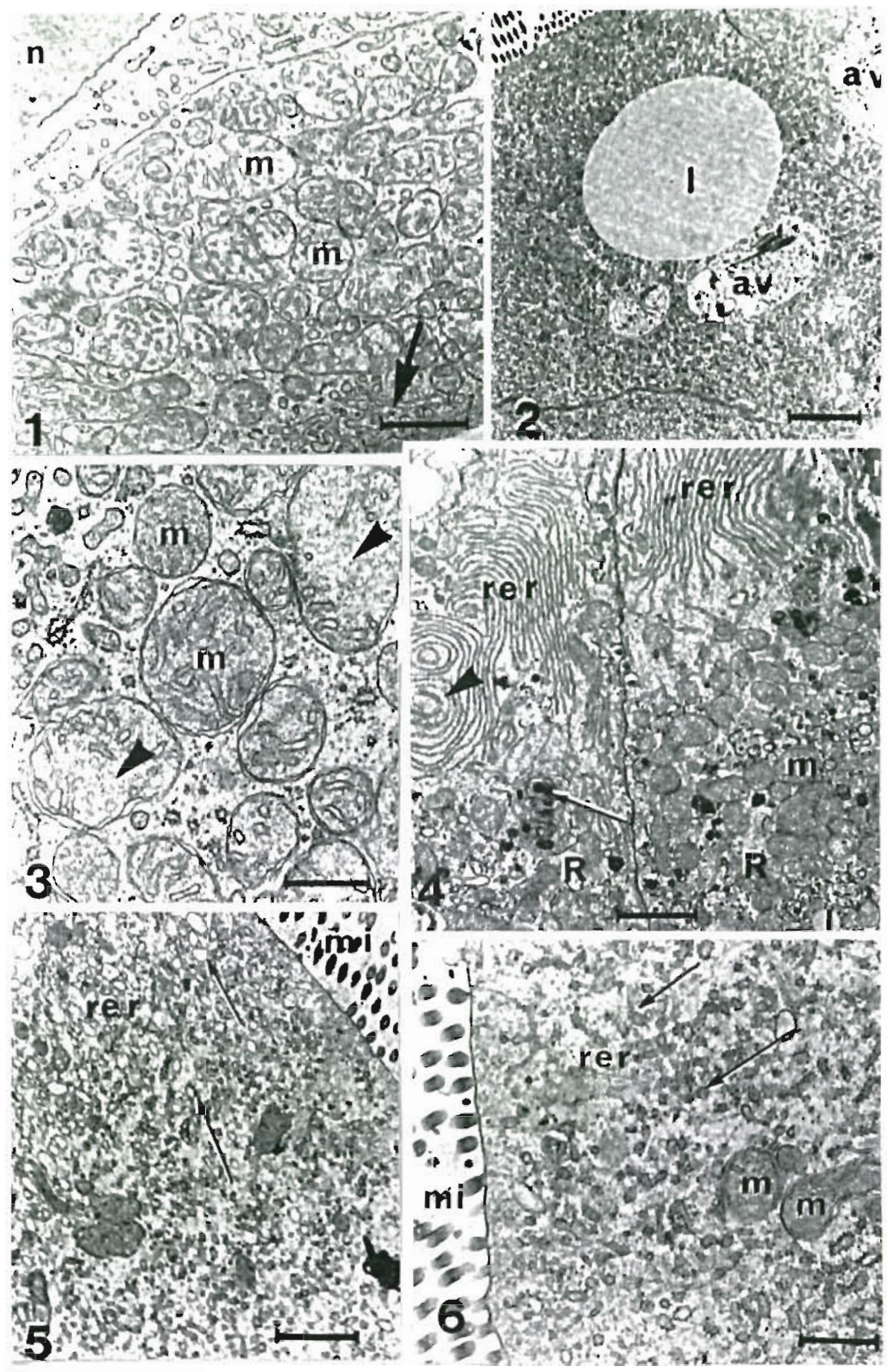

Fig. 3. Palaemon serratus. Electron micrographs. (1) Basal region of an absorptive cell after exposure to 5 ppm cadmium; note fewer vesicles associated with infoldings of basal membrane (arrow); scale bar $=1 \mu \mathrm{m}$. (2) Apical region of an absorptive cell after exposure to $5 \mathrm{ppm}$ cadmium; note presence of autophagic vacuoles (av); scale bar $=2 \mu \mathrm{m}$. (3) Mitochondna (m) in an absorptive cell after exposure to $5 \mathrm{ppm}$ cadmium; note cristae-free areas un some of these mitochondna (arrowheads); scale bar = $0.5 \mu \mathrm{m}$. (4) Two absorptive cells (R) after exposure to $25 \mathrm{ppm}$ cadmium; note fewer mitochondria (m) concentrated at basal region of the cells, vacuoles (arrow) and concentnc whorls of the rough endoplasmic retıculum (arrowhead); scale bar $=2.5 \mu \mathrm{m}$. (5) Apical region of an absorptive cell after exposure to $5 \mathrm{ppm}$ cadmium; note vesıcular form of rough endoplasmic retıculum (arrows); scale bar $=1 \mu \mathrm{m}$. (6) Apical region of an absorptive cell after exposure to $25 \mathrm{ppm}$ cadmium; note vesicular form of rough endoplasmic reticulum (arrows) and small mitochondna $(\mathrm{m})$; scale bar $=0.6 \mu \mathrm{m}$. l hpid; $\mathrm{n}$ : nucleus; m: mitochondna; mi: microvillı; rer: rough endoplasmic reticulum 


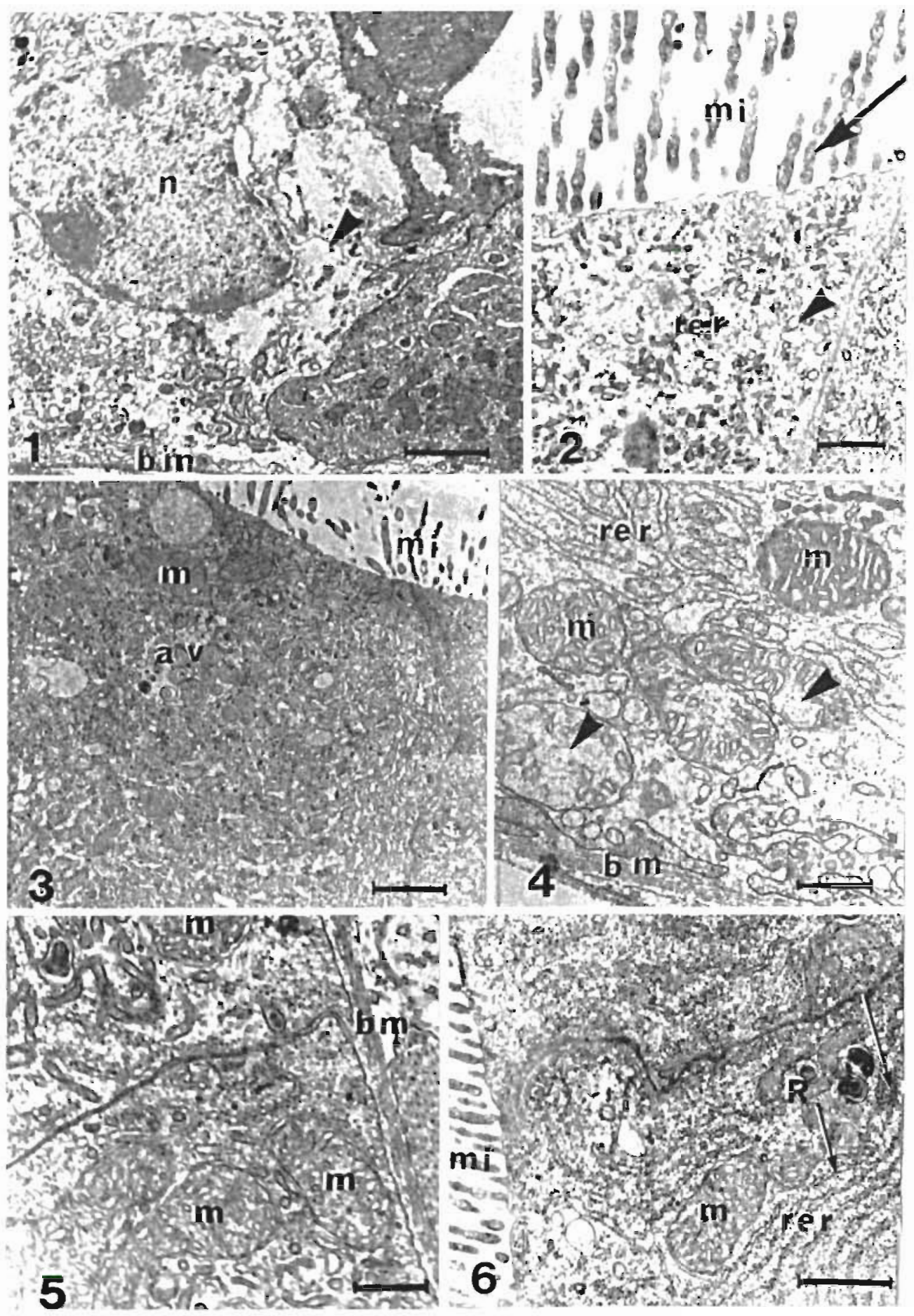

Fig. 4. Palaemon serratus. Electron micrographs (1) Basal region of R-cell after exposure to 50 ppm cadmium; note disruption of the 2 membranes of the nuclear envelope (arrowhead), scale bar $=2 \mu \mathrm{m}$. (2) Apical region of absorptive cell after exposure to 50 ppm cadmium; note appearance of microvill (arrow) and vesıcular form of rough endoplasmic reticulum (arrowhead); scale bar $=0.5 \mu \mathrm{m}$. (3) Apical region of absorptive cell after exposure to $50 \mathrm{ppm}$ cadmium; note fewer microvilli and fewer but larger mitochondria; scale bar $=1.3 \mu \mathrm{m}$. (4) Basal region of absorptıve cell after exposure to $50 \mathrm{ppm}$ cadmium; note appearance of mitochondna with fewer and swollen cristae (arrowheads); scale bar $=0.6 \mu \mathrm{m}$. (5) Basal region of absorptive cell after exposure to $25 \mathrm{ppm}$ cadmum; note fewer infoldings of basal membrane; scale bar $=0.6 \mathrm{um}$. (6) Apical region of absorptive cell ( $R$ ) after exposure to $25 \mathrm{ppm}$ cadmium, note appearance of endoplasmic reticulum as thin, short cisternae (arrows); scale bar $=1 \mu \mathrm{m}$. av: autophagic vacuole; bm: basal membrane; m mitochondria; mi. microvilli n nucleus; rer. rough endoplasmic reticulum 


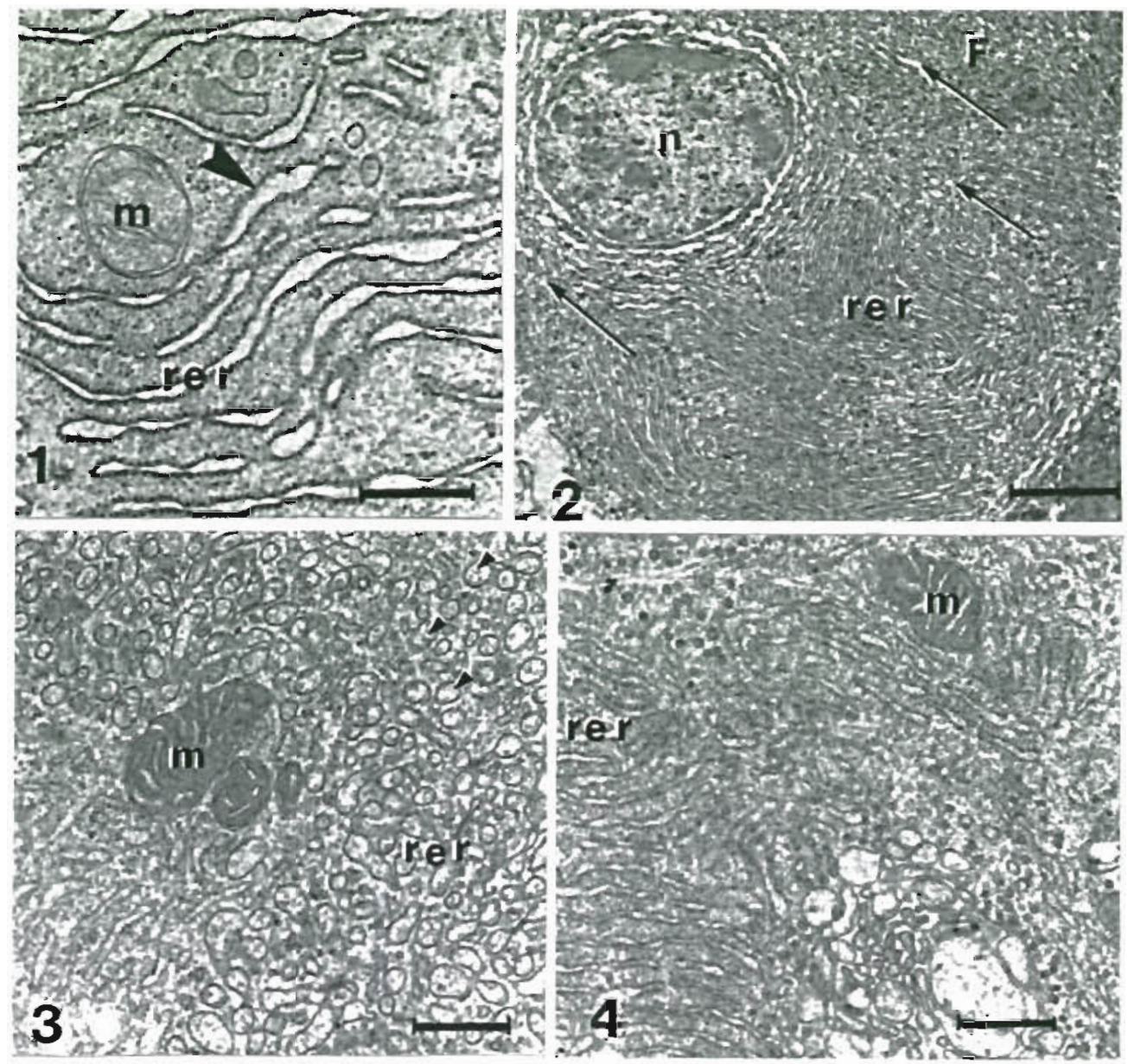

Fig. 5. Palaemon serratus. Electron micrographs. (1) Rough endoplasmic retıculum in a fibrillar cell after exposure to 5 ppm cadmium; note dilation of cisternae (arrowhead); scale bar $=05$ um. (2) Fibrllar cell (F) after exposure to 25 ppm cadmium; note shorter cisternae of rough endoplasmic reticulum (arrows); scale bar $=4 \mu \mathrm{m}$. (3) Fibrillar cell after exposure to 50 ppm cadmium: note short cisternae of rough endoplasmic reticulum (arrowheads); scale bar $=06 \mu \mathrm{m}$. (4) Fibrillar cell after exposure to 50 ppm cadmium; note extended cisternae of rough endoplasmic retıculum; scale bar $=0.6 \mu \mathrm{m}$. $\mathrm{m}$ mitochondna; $\mathrm{n}$. nucleus, rer' rough endoplasmıc reticulum

hepatopancreas; therefore, as a result, Cd accumulation was higher in hepatopanceas than in gills. This is in contrast to Vernberg \& O'Hara's (1972) reports for the same species when exposed to sublethal concentrations of mercury $(0.18 \mathrm{ppm})$. They found that gill tissue accumulated more mercuric ions than the hepatopancreas, regardless of experimental conditions. In Palaemon serratus tissue breakdown was observed after high exposure to cadmium in the gills but not in the hepatopancreas (Papathanassiou \& King 1983). The gills of $P$. serratus seem to be able to translocate cadmium to the hepatopancreas, since the accumulation in this tissue was always higher than in the gills (Papathanassiou \& King 1983).

After $\mathrm{Cd}$ exposure, $\mathrm{R}$ - and F-cells differ from those in clean fed specimens, the differences being more pronounced in the highest concentrations. The dissociation observed in the infoldings of the basement mem- brane in R-cells from both the smooth endoplasmic reticulum and mitochondria is a result of exposure to cadmium solutions, with the maximum effect when individuals were exposed to $50 \mathrm{ppm}$ cadmium. Similar dissociation of the infolded basement membrane from mitochondria was also observed in the gills of Jaera nordmanni (Rathke), after exposure to cadmium, mercury or copper ions (Bubel 1976).

The results obtained from the present study resemble the changes which occurred in Crustacea after nutritional stress (Papathanassiou \& King 1984, Storch \& Burkhardt 1984). The differences, however, after $\mathrm{Cd}$ exposure were more severe in regard to mitochondnal changes and the association of these organelles with infoldings of the basal membrane and the endoplasmec reticulum (Papathanassiou \& King 1984).

The apical part of R-cells, which is specialized for absorption, loses its organızation and therefore cad- 
mium could affect the transfer of fluid to and from the lumen. Mitochondrial changes in R-cells after $\mathrm{Cd}$ exposure suggest that $\mathrm{Cd}$ ions may affect the energy of those cells by combining with enzymes and inhibiting the membrane ATPase system in the mitochondria. The latter is well known as one of the most important targets of heavy metals in cells (Viarengo 1985). Similar inhibition of enzymes in mitochondra has been suggested for gills of other crustaceans, including Jaera nordmanni, Oronectes rusticus (Girard) and Palaemon serratus after exposure to heavy metals (Hubschman 1967, Bubel 1976, Papathanassiou \& King 1983).

Infoldings of the basement membrane of R-cells, with the associated smooth endoplasmic reticulum and mitochondria, are involved in ion transport (Papathanassiou \& King 1984). A similar function of the basal region complex has been reported by Clifford \& Witkus (1971) in the absorptive cells of the isopod Oniscus ascellus. Dissociation of mitochondria with infoldings of the basal cell membrane after exposure to cadmium is disrupted; this implies disturbance in ion transport.

The rough endoplasmic reticulum of F-cells in affected specimens of Palaemon serratus has the form of short cisternae. It has been reported previously that maximum enzyme activity prevails in a disorientated endoplasmic reticulum characterized by distended cisternae (Siekevitz \& Palade 1958). Therefore, the form of the rough endoplasmic reticulum, in connection with the smaller number of mitochondria, could indicate inhibition of protein-secreting mechanisms by cadmium ions. In support of this suggestion Viarengo et al. (1980) found the cadmium, copper and mercury are able to reduce the rate of protein synthesis in the tissues of Mytilus galoprovincialis. The secretory mechanism does not seem to be disrupted by cadmium ions, since there are no observable differences in affected B-cells.

The changes observed in R-cells and F-cells of the hepatopancreas of Palaemon serratus document that cadmium affects several processes within these cells, including ion transport, absorption and protein synthesis.

Acknowledgements. We thank Professor E. W. Knight-Jones in whose department this study was carried out; and Dr. M. Fordy for technical assistance in electron microscope work.

\section{LITERATURE CITED}

Abdullah, M. I., Royle, L. G., Morris, A. W., (1972). Heavy metals concentrations in coastal waters. Nature, Lond 235: 158-160
Bubel, A. (1976). Histological and electron microscopical observations on the effects of different salinities and heavy metals ions on the gills of Jaera nordmanni (Rathke) (Crustacea, Isopoda). Cell Tiss. Res. 167: 65-95

Bunt, A. H. (1968). An ultrastructural study of the hepatopancreases of Procambarus clarkii (Girard) (Decapoda, Astacidea). Crustaceana 15: 282-288

Clifford, B., Witkus, E. R. (1971). The fine structure of the hepatopancreas of the woodlouse, Oniscus ascellus. J. Morph. 135: 335-350

Davis, L. E., Burnett, A. L. (1964). A study of growth and cell differentiation in the hepatopancreas of crayfish. Devl Biol. 10: 122-153

Donadey, M. C. (1969). La fonction absorbante des caecums digestifs de quelques crustaces isopodes marins, etudiéée au microscope electronic. C. R. hebd. Séanc. Acad. Sci. Paris 268: 1607-1609

Gibson, R., Barker, P. L. (1979). The decapod hepatopancreas. Oceanogr. màr. Biol. A. Rev. 17: 285-346

Hubschman, J. H. (1967). Effects of copper on the crayfish, Oronectes rusticus (Girard). II. Mode of toxic action. Crustaceana 12: 141-151

Hutcheson, M. S. (1974). The effect of temperature and salinity on cadmium uptake by the blue crab, Callinectes sapidus. Chesapeake Sci. 15: 237-241

Loizzi, R. (1971). Interpretation of crayfish hepatopancreatic function based on fine structural analysis of epithelial cell lines and muscle network. Z. Zellforsch. mikrosk. Anat. 113: $420-440$

Nimmo, R. D. W., Lightner, V. D., Bahner, H. L. (1977). Effects of cadmium on the shrimps, Penaeus duorarum, Palaemonetes pugio and Palaemonetes vulgaris. In: Vernberg, F. J., Calabrese, A., Thurberg, F. P., Vernberg, W. B. (ed.) Physiological responses of marine invertebrates to pollutants. Academic Press, New York, p. $131-138$

O'Hara, J. (1973a). The influence of temperature and salinity to fiddler crab, Uca pugilator. Fish. Bull. U. S. 71: 149-153

O'Hara, J. (1973b). Cadmium uptake by fiddler crabs exposed to temperature and salinity stress. J. Fish. Res. Bd Can. 30: 846-848

Papathanassiou, E., King, P. E. (1983). Ultrastructural studies on the gills of Palaemon serratus (Pennant), in relation to cadmium accumulation. Aquat. Toxicol. 3: 273-284

Papathanassiou, E. (1984). Effects of cadmium and mercury ions on respiration and survival of Palaemon serratus (Pennant). Rev. Int. Oceanogr. Med. 72: 21-35

Papathanassiou, E., King, P. E. (1984). Effects of starvation on the fine structure of the hepatopancreas in the common prawn Palaemon serratus (Pennant). Comp. Biochem. Physiol. 77: 243-250

Preston, A. (1973). Heavy metals in British waters. Nature, Lond. 242: 95-97

Siekevitz, P., Palade, G. E. (1958). A cytochemical study on the pancreas of the guinea pig. II. Functional variations in the enzymatic activity of microsomes. J. biophys. biochem. Cytol. 4: 309-333

Stanier, J. E., Woodhouse, M. A., Griffin, R. L. (1968). The fine structure of the hepatopancreas of Carcinus maenas (L.) (Decapoda, Brachyura). Crustaceana 14: 56-66

Steeves, H. R. (1969). Lipid content of the hepatopancreas of the isopod Bathynomus gigantus H. Milne-Edwards. Crustaceana 16 : 135-138

Storch, V., Burkhardt, P. (1984). Influence of nutritional stress on the hepatopancreas of Talitrus saltator (Peracarida, Amphipoda). Helgoländer Meeresunters. 36: 65-73

Vernberg, W. B., O'Hara, J. (1972). Temperature-salinity 
stress and mercury uptake in the fiddler crab, Uca pugilator. J. Fish. Res. Bd Can. 29: 1491-1494

Viarengo, A., Pertica, M., Mancinelli, G., Capelli, R., Orunesu, M. (1980). Effects of copper on the uptake of aminoacids on protein synthesis and on ATP content in different tissues of Mytillus galloprovincialis Lam. Mar. Environ. Res. 4: 745-752
Viarengo, A. (1985). Biochemical effects of trace metals. Mar. Pollut. Bull. N. S. 16: 153-158

Vonk, H. J. (1960). Digestion and metabolism. In: Waterman, T. H. (ed.) Physiology of Crustacea, Vol. I. Metabolism and growth. Academic Press, New York, p. 291-316

Responsible Subject Editor: Dr. K. Rohde; accepted for printing on September 12, 1986 